\title{
INFLUENCE OF CONDITIONS OF ECONOMIC SYSTEMS ON INNOVATION PROCESSES IN MODERN INTERNATIONAL ECONOMIC ENVIRONMENT
}

\author{
Inta Kotane \\ Rezekne Academy of Tehnologies, Latvia
}

Irina Yegorova

Kryvyi Rih Economic Institute of Kyiv National Economic University named after Vadym Hetman, Ukraine

\section{Hanna Puriy}

Kryvyi Rih Economic Institute of Kyiv National Economic University named after Vadym

Hetman, Ukraine

\section{Serhii Hushko}

Polonia University in Czestochowa, Poland

\section{Volodymyr Kulishov}

Polonia University in Czestochowa, Poland

\begin{abstract}
The purpose of the paper is to analyse the relationship between the state of economic systems and the innovative activity of industrial enterprises in accordance with the peculiarities of the development of national economies in the global economic environment. The general scientific research methods are used in the research study: information analysis and synthesis, logical construction, monographic, data grouping, and graphical display methods. The character of the influence of a stable economic system (on the example of Latvia) and an unstable economic system (on the example of Ukraine) on innovative development is established. The main factors stimulating innovations in different national conditions in the context of modern international trends of innovative development are revealed. The main directions of the impact on innovation processes and the principles of innovation development policy are defined.
\end{abstract}

Keywords: crisis phenomena, economic systems, global innovation index, innovation, policy of innovation development, stable development.

\section{Introduction}

Innovations are a necessary condition for the development of most economic systems at various levels (namely, enterprises, industries, national economies) in the modern international economic environment. It is also advisable to consider 
the innovative activity of the entities of international business as one of the main means of adapting to the constant changes that occur in the economic, social and civilizational space at the micro, macro and mega levels. This is ensured by a special process of managing the economy, based on the constant search for new opportunities to improve the technical, technological, organizational and other factors of the production process.

Crisis phenomena that affect the results of economic activity of many companies, individual countries and the world economy as a whole negatively affect the internal and external environment of business entities. They significantly inhibit innovative processes, which in turn act as a catalyst for all activities. As a result, the innovation activity of industrial enterprises is reduced, the pace of scientific and technical progress is slowing down, the demand for innovative products is reduced, and the possibilities for applying advanced technologies are reduced. All this leads to a decrease in the competitive advantages of products and the competitive positions of individual enterprises in national and international markets, and also contributes to a decrease in the competitiveness of economies of whole countries.

At the same time, taking into account the dynamics of innovation activity in the countries of the world, one can also say the opposite: it is the crisis of innovations that causes stagnation processes in national and world economic systems.

Determining the nature of the mutual influence of the state of economic systems and innovation processes is part of the scientific interests of many scientists.

Aljanabi (2017) studied the relationship between entrepreneurial orientation, absorptive capacity, and technological innovation capabilities among industrial small and medium-sized enterprises (SMEs) operating in an unstable environment. It was concluded that entrepreneurial orientation and absorptive capacity have significant effects on technological innovation capabilities. However, during the analysis of the mediating effects of incremental and radical innovation within the context of entrepreneurial firms in Turkey, an emerging economy (Kocak et al., 2017), it was concluded that proactive market orientation and technology orientation lead to radical innovation, while responsive market orientation strongly affects incremental innovation.

Researchers (Do et al., 2014) have studied how SMEs manage their innovation and identify critical factors determining the potential innovation outcomes. Forsman and Rantanen (2011), exploring innovation development in enterprises with fewer than 50 employees and small manufacturing and service enterprises, concluded that there exists a broad diversity of innovation patterns among small enterprises. The differences and similarities of innovation capacity and innovation development could be identified across the companies of different 
size categories within the manufacturing and service sectors. Saunila (2017) focuses on the challenges and characteristics of innovation performance measurement in SMEs.

Spanish researchers (Serrano-Bedia et al., 2012) have analysed the existence of complementarity between innovation activities (internal innovation, external innovation and cooperative R\&D), as well as their impact on firms' innovation performance.

Denins and Lipman (Deninšs, Lipmans, 2011) have studied the management of innovations in Latvian companies and their impact on the competitiveness of the business. The survey conducted by the authors shows that Latvian entrepreneurs lack a systematic approach to innovation management, and there is a lack of resources for consistent implementation of innovation policy.

However, a number of publications are limited to analysis of the interaction between innovation activity and the state of economic systems of the same level, namely, enterprises.

Global aspects of the innovative development of economic systems remain unresolved, namely, the features of innovative development of systems in a stable and volatile economy.

Despite the significant results achieved by scientists in the study of the state of economic systems and their impact on innovation, it should be noted that innovative processes, as well as the crisis phenomena of the development of economic systems, require constant monitoring, study of dynamics and interconnection already taking into account modern internal and external conditions of functioning of the national and world economy.

The purpose of the paper is to analyse the relationship between the state of economic systems and the innovative activity of industrial enterprises in accordance with the peculiarities of the development of national economies in the global economic environment. Studying the influence of stability and instability of economic systems on innovative development will help to identify the main factors that stimulate innovation in various external national and international conditions, which helps determine the key directions of the impact on innovation processes.

The general scientific research methods are used in the study: information analysis and synthesis, logical construction, monographic, data grouping, and graphical display methods.

\section{Main research findings Latvia}

The globalization has an impact on the growth and competitiveness of enterprises, in particular SMEs, which are increasingly dependent on enterprise 
investments in innovation. The definition of innovation adopted in Latvia states that "innovation is a process in which new ideas, developments and technologies in the scientific, technical, social, cultural and other fields are realized in a competitive product or service that is in demand on the market" (Zinātniskās darbības likums, 2005; Par Nacionālo inovāciju programmu 2003.-2006.gadam).

In Latvia, the Ministry of Economics is the leading institution of public administration in the field of economic policy. Its tasks and competencies include the development and implementation of the policy of innovation development. The main national priorities, activities and measures taken to promote industrial development, financial accessibility, promotion of innovation and export, and improvement of the business environment are included in the programme "Guidelines for the National Industrial Policy for 2014-2020" (Nacionālās industriālās politikas ..., 2013). Innovation and build-up of innovative potential within the framework of the Latvian National Industrial Policy are one of the cornerstones for increasing the competitiveness of Latvia's industries and increasing productivity and export volumes. The main directions outline four equally important elements for the development of the Latvian innovation system - the potential of knowledge, the innovative proposal, the demand for innovation, the transmission system. At the same time, the objectives and directions of the innovation policy are also set out in the "Guidelines for Science, Technology and Innovation Development for 2014-2020" (Zinātnes un tehnoloǵijas attīstības ..., 2013).

In the Global Innovation Index, 127 countries of the world were assessed on 81 indicators for various factors affecting innovation, including the political environment, education, infrastructure and enterprise development. The global innovation index of the current year shows the situation in the previous year. In the annual global innovation index in the period from 2011 to 2017, Latvia showed the highest result in 2011, when the country ranked 30th in the index published in 2012 (see Figure 1). In subsequent years, the result of Latvia is 33rd or 34th place. Among the Baltic countries - assessing the indicators of Latvia, Lithuania and Estonia - Latvia in the period under review shows average indicators. In the last Global Innovation Index of 2017, Latvia ranks 33rd. This is better than Lithuania, ranking 40th, but worse than Estonia, which is recognized as the 25th most innovative country in the world.

In the Global Innovation Index of 2017 for the seven categories of indicators, Latvia's best results were in the category of creative activity, in which Latvia ranks 14th in the world. In the category of institutions (institutions), Latvia is the 28th best in the world, in the market development category it occupies 38th place, in the category of business development - 39th place, in the category of infrastructure - 42nd place, in the category of knowledge and technology - 48th 
place, and in the category of human capital and research, Latvia is recognized as the 52nd strongest in the world.

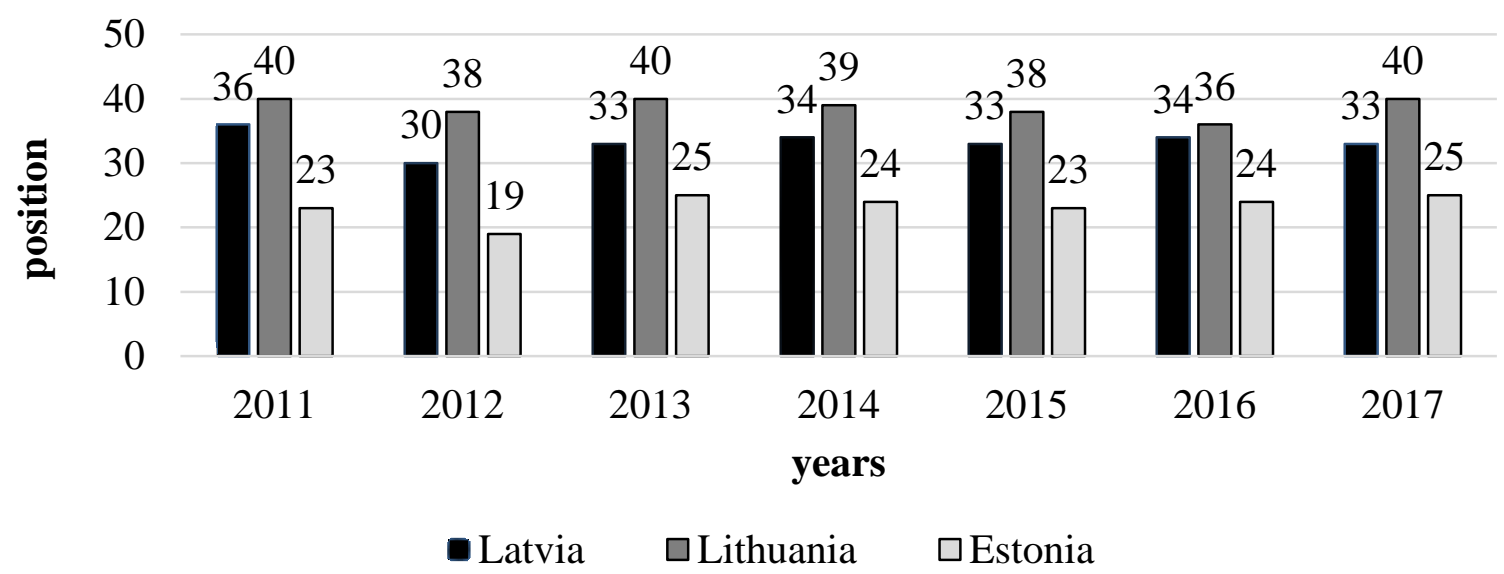

Figure 1. Changes in the positions of Latvia, Lithuania and Estonia in the Global Innovation Index in 2011-2017 (The Global Innovation Index, 2017)

However, the European Innovation Scoreboard, developed by the European Commission (EC), includes 10 measurements, taking into account 27 indicators affecting innovation, in such areas as human resources, an attractive research system, an environment conducive to innovation, finance and support, investment in business, the ability to innovate enterprises, the cooperation of science and entrepreneurship, intellectual assets, the impact of innovation on employment, and the impact of innovation on sales.

Taking into account the average results of innovation, the EU Member States are divided into four groups according to the performance. Latvia belongs to the group of medium innovators, as a country with innovative indicators from $50 \%$ to 90\% of the EU-28 average (European Commission, 2017).

Assessing the indicators of the development of innovations of the countries of the European Union (EU) in 2015, the EU gave a high assessment of Latvia's achievements, as a result of which Latvia for the first time in the Report on the Innovation Union published annually by the EU took a place in the group of "medium innovators".

EU experts appreciated measures taken by Latvia to create a favourable business environment for innovation, as well as to develop human resources and employment in knowledge-intensive and fast-growing companies. In the rating of the Innovation Union of 2017, Latvia took 24th place among 28 countries, having risen by one place in comparison with the results of 2016 .

The estimation of Latvia in the latest innovation ratings is proof of stable and sustainable development of the country. This is a confirmation of the fact that the movement is taken in the right direction - to the purposeful development of 
innovation policy, which will contribute to the increase in productivity and growth in the output of products with high value added, which is indispensable for more rapid growth of the Latvian economy. Satisfaction from the recognition received for the done work in the sphere of improving the business environment, human resources development and employment contributes to the further development of innovations in Latvia (Ekonomikas ministrija, 2017a).

Despite positive trends in the field of innovation, assessing the Latvian innovation system from the point of view of business or demand, the following shortcomings are underlined: limited opportunities for enterprises to invest in research, development, technology; insufficiently developed technology transfer infrastructure; weak cooperation between entrepreneurs and the research sector; insufficiently developed corporate culture of network development and cluster cooperation; lack of motivation, as business strategies of enterprises are not oriented to innovation, etc. (Ekonomikas ministrija, 2017b).

The Ministry of Economics of Latvia has set a goal ((Ekonomikas ministrija, 2017b): in the Global Innovation Index, Latvia should take 25th place out of 127 countries, and in the European Innovation Scoreboard to take 20th place among 28 EU countries.

Achievability of the goals set by Latvia in the field of innovation will be visible in the future, but an analysis of the current situation shows that Latvia has all the prerequisites for achieving them.

\section{Ukraine}

Crisis phenomena have become a daily occurrence for the modern enterprises of Ukraine, functioning in the conditions of an unstable economy for a long period. However, for some economic entities, economic cycles acted as a catalyst for further economic growth, and for others - a factor in the aggravation of functioning, which led to a deterioration in business conditions, losses or bankruptcy. It should be noted that innovation-active enterprises demonstrated not only a high development potential, but also high adaptability to external negative business conditions. The crisis phenomena of instability were reflected in the rating of innovative development of Ukraine.

In the annual Global Innovation Index in 2017, Ukraine rose by 6 positions, taking 50th place (see Figure 2). 
Proceedings of the International Scientific Conference. Volume VI, May $25^{\text {th }}-26^{\text {th }}$, 2018. 294-303

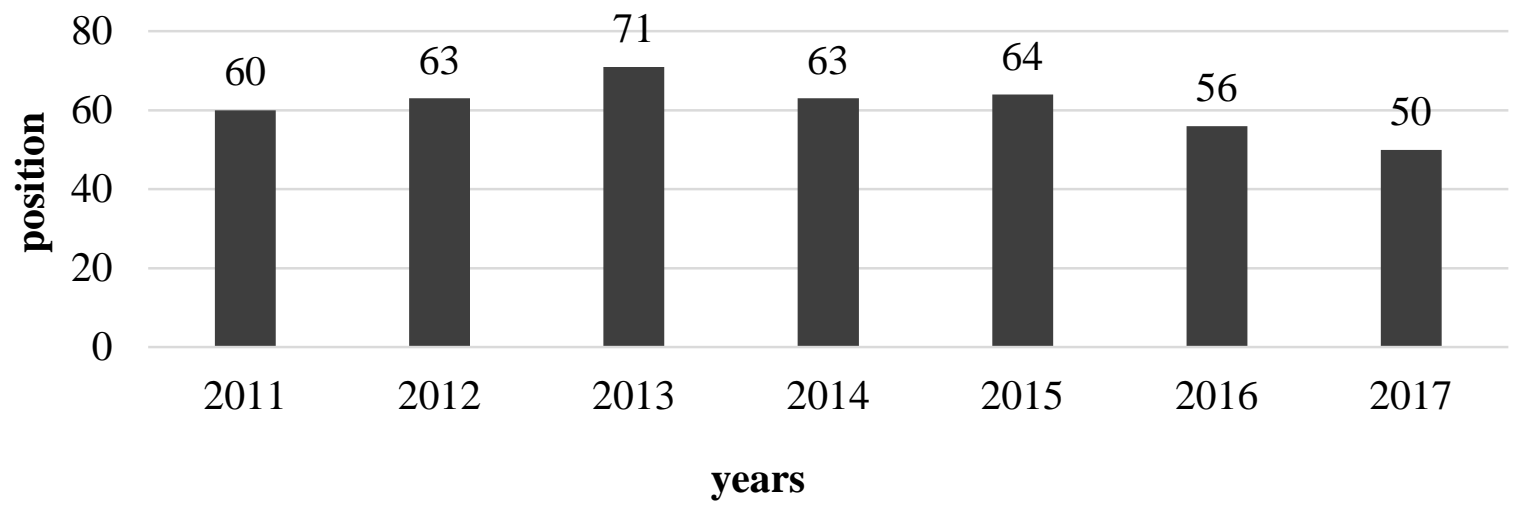

Figure 2 Position of Ukraine in the Global Innovation Index in 2011-2017 (The Global Innovation Index, 2017)

For ten years, during which the calculation of the index published by Cornell University, the INSEAD business school and the World Intellectual Property Organization was carried out, this is the highest level for Ukraine. In total, the rating included 127 countries. The seventh time in a row, the leader of the rating was Switzerland. It was followed by Sweden, the Netherlands, the United States, Great Britain, and Denmark.

Ukraine in 2017 is located between Qatar and Thailand, which occupy 49th and 51st place, respectively. The Ukrainian economy, according to the rating, is in the group of countries with lower than average income.

The jump by six positions in the overall rating provided Ukraine with improvements in key sub-indices: political stability and lack of violence / terrorism (124th position), rule of law (110th position), ease of business creation (18th position), simplicity of tax payment (66th position), etc.

At the same time, such indicators as government effectiveness (96th position) and simplicity of insolvency resolution (120th position) negatively influenced the innovation index of Ukraine in 2017.

It should be noted that, in the ranking of the 50 most innovative countries of the world published by Bloomberg, Ukraine in 2017 ranked 42nd, dropping for one year by one position. Among the indicators that positively influenced the place of Ukraine in the rating, experts noted the high level of education of the population, the susceptibility to new technologies and the availability of scientific potential. However, the country's innovative development is hampered by low labour productivity and a small number of technology companies (Bloomberg Global Business Forum, 2017).

Ukrainian industry possesses a significant innovative potential capable of providing structural transformation of the national economy and a high level of scientific and technological development of the country as a whole. At the same time, in Ukraine, until now, the reserves of production capacities that were not used during the crisis period and the favourable external economic conditions 
served as the dominant sources of industrial growth. Preservation of the existing model of development of Ukraine's industrial sector with a focus on lowtechnology production and exports may lead to a decrease in the competitive positions of the national economy and further increase the technological gap from the economically developed countries of the world.

In fact, this is observed in the innovation sector in recent years. The state of the innovative sphere of Ukraine was devastatingly affected by the global financial and economic crisis of 2008-2009. During this period, the indicators of innovation activity had a predominantly downward trend. At the same time, for the indicators of innovative activity of industrial enterprises in Ukraine in the post-crisis period and the period of economy stagnation, the positive dynamics was characteristic. An exception was the change in the values of key indicators of the innovation process: the volume of financing innovative activity, the share of innovative products in the total volume of industrial products sold, and the export of innovative products produced by industrial enterprises, which deteriorated sharply during the period of economic stagnation (2011-2012) (State Statistics Service of Ukraine, 2017).

Thus, the functioning of industrial enterprises in Ukraine in an unstable national economy is accompanied by a decrease in the activity of the innovation process. After all, Ukraine continues to develop without significant use of its innovative potential, and the development of innovative products is carried out primarily through the use of scientific and technological achievements of previous years (Kulishov, 2013). This type of innovative development has rather narrow boundaries and does not provide opportunities to maintain the competitiveness of Ukrainian enterprises in the domestic and international markets for a long period. At the same time, the crisis phenomena of an unstable economic system adversely affected innovation activity, led to a reduction in the financing of innovative research and development, a reduction in the share of exports of innovative products in the total volume of sales of industrial products. As a result, it significantly reduced the rating of Ukraine and enterprises of the industrial sector of the national economy in the global innovation environment.

\section{Conclusions}

The world community realizes that the innovative economy has become a key component of post-industrial progress, a strategic resource, a generally recognized development trend in the long term.

Taking into account the realities of the 21st century, the EU countries, and Latvia in particular, are implementing strategies for accelerating the development of the innovation economy both to overcome the global crisis and to support the 
financial system of Europe, taking into account the problems of economic stability.

Summarizing the experience of developing a stable Latvian economy through the implementation of an active innovation policy, it is proposed to use the main directions of the impact on innovative processes that have found application in Latvia, to overcome the crisis phenomena and to ensure the effective development of the unstable economy of Ukraine on an innovative basis.

In this regard, at the stage of formation of a competitive market environment, it is recommended to implement innovative policy in Ukraine on the principles that would form a certain strategy and tactics aimed at achieving certain goals of the country's socioeconomic development in an unstable economy. In our opinion, the innovation policy of the national economic system should be based on such important principles: systemic, integrated, manageable, purposeful, continuous, timeliness, optimality, continuity, consistency, irreversibility, justified risk, maximum consideration of the interests of the subjects of the innovation process.

The conducted research studies showed that the general characteristic feature of the functioning of stable and unstable economic systems at different levels is the inadequacy of attracting investment funds in the development of innovations. Therefore, the policy of innovation development should be oriented towards the international system model of innovation, ensuring the socio-economic consolidation of territories, the introduction of information and communication technologies and the modernization of industry at the mega- and macroeconomic level. At the same time, the development of international franchising business is a promising direction for the development of innovations at the microlevel, which does not require significant capital investment and allows the introduction of modern achievements of international business organizations.

\section{References}

Aljanabi, AbdulQadir, R, A. (2017). The mediating role of absorptive capacity on the relationship between entrepreneurial orientation and technological innovation capabilities. International Journal of Entrepreneurial Behavior \& Research, pp.13552554.

Bloomberg Global Business Forum (2017). Bloomberg Finance. Retrieved: https://www.bloomberg.com/global-business-forum-2017, sk.29.01.2018.

Deniṇš, A., \& Lipmans, F. (2011). Inovāciju vadība Latvijas uzṇēmumos un to ietekme uz uzñēmumu konkurētspēju. Latvijas Universitātes raksti. Ekonomika. Vadības zinātne, 771.sēj, 442.-456.lpp.

Do, T.H., Mazzarol, T., Volery, T., \& Reboud, S. (2014). Predicting anticipated rent from innovation commercialisation in SMEs, European Journal of Innovation Management, Vol. 17, Issue: 2, 183-208.

Ekonomikas ministrija (2017a). Latvijas novērtējums starptautiskajos inovāciju reitingos apliecinājums stabilai un ilgtspējīgai valsts attīstībai. Pieejams: https://goo.gl/yPPM9u 
Kotane et al., 2018. Influence of Conditions of Economic Systems on Innovation Processes in Modern International Economic Environment

Ekonomikas ministrija (2017b). Inovāciju politika. Pieejams: www.lizda.lv/content/files/ Inovacija_NTPS.pdf

European Commission (2017). European Innovation Scoreboard. Retrieved: http://ec.europa. eu/growth/industry/innovation/facts-figures/scoreboards_lv, sk.29.01.2018.

Forsman, H., \& Rantanen, H. (2011).Small manufacturing and service enterprises as innovators: a comparison by size, European Journal of Innovation Management, Vol. 14, Issue: $1, .55$ Issue: 2, pp.248-270.

Kulishov, V. (2013). Trends and challenges of innovation economy. Journal of European economy, 12 (3), 324-333.

Nacionālās industriālās politikas pamatnostādnes 2014.-2020.gadam (2013). Ministru kabineta rīkojums Nr.282. Pieejams: http://polsis.mk.gov.lv/documents/4391

Par Nacionālo inovāciju programmu 2003.-2006.gadam. (2003). Ministru kabineta rīkojums Nr.205. Pieejams: https://goo.gl/oXkEps

Saunila, M. (2017). Understanding innovation performance measurement in SMEs, Measuring Business Excellence, Vol. 21, Issue: 1,.1-16.

Serrano-Bedia, Ana Ma., López-Fernández, Ma, C., \& García-Piqueres, G. (2012). Complementarity between innovation activities and innovation performance: Evidence from Spanish innovative firms, Journal of Manufacturing Technology Management, Vol. 23, Issue: 5, 557-577.

State Statistics Service of Ukraine (2017). Retrieved from http://www.ukrstat.gov.ua

The Global Innovation Index (2017). The Local Dynamics of Innovation. Retrieved: https://www.globalinnovationindex.org/analysis-economy

Zinātnes un tehnologijas attīstības un inovācijas pamatnostādnes 2014.-2020.gadam (2013). Ministru kabineta rīkojums Nr.685. Pieejams: http://polsis.mk.gov.lv/documents/4608

Zinātniskās darbības likums (2005). LR likums. Pieejams: https://likumi.lv/doc.php?id=107337 